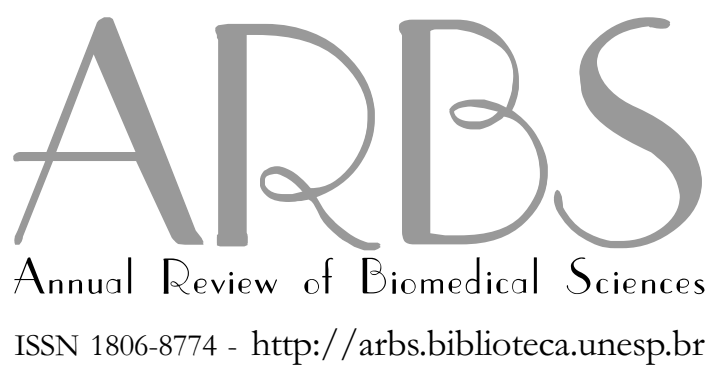

\title{
Aunesp
}

\section{Direct Effects of Leptin on Gonads, Gametes, and Embryos: Is Too Much a Bad Thing?}

\author{
Swain $\mathrm{JE}^{1}$, Smith $\mathrm{GD}^{2}$ \\ ${ }^{1}$ Department of Molecular \& Integrative Physiology, Reprodutive Sciences Program, School of Medicine, \\ University of Michigan; ${ }^{2}$ Dept. of Physiology, Obstetrics \& Gynecology, Urology, Reproductive Sciences Program, \\ University of Michigan, 6428 Medical Sciences I, 1301 E. Catherine St., Ann Arbor, MI, 48109-0617, USA. \\ ${ }^{2}$ Corresponding author
}

\section{Abstract}

Swain JE, Smith GD. Direct Effects of Leptin on Gonads, Gametes, and Embryos: Is Too Much a Bad Thing? ARBS Ann Rev Biomed Sci 2004;6:99-108. Originally discovered as a satiety factor and regulator of metabolism and fat deposition, emerging data suggest a role for leptin in regulation of reproductive function. The vast majority of research in this area focuses on the role of leptin in regulation of neuroendocrine function and the effects of the hormone on the hypothalamo-pituitary-gonadal axis. However, evidence exists indicating a direct role of leptin in regulation of the gonads, gametes and preimplantation embryos. The presence of leptin, its receptor, as well as studies demonstrating effects on function, development and activation of transcriptional and signal transduction pathways, all support the notion that leptin is directly affecting the ovary, testis, oocyte, spermatozoan and preimplantation embryo. These direct effects may be associated with reduced fertility.

Key-words: leptin, oocyte, ovary, sperm, testis, embryo.

Received: 09/09/04 Accepted: 15/11/04

\section{Table of Contents}

Introduction

Leptin and the Ovary

Leptin and the Testes

Leptin and the Oocyte

Leptin and Spermatozoa

Leptin and the Preimplantation Embryo

Concluding Remarks

Acknowledgments

References 


\section{Introduction}

Since its discovery, leptin has been the focus of an immense amount of scientific research. A vast majority of this work has focused on leptin's role in regulation of weight gain and fat deposition. A $16-\mathrm{kD}$ a protein product of the obese gene, leptin is a satiety hormone primarily secreted by mature adipocytes and is involved with the regulation of appetite and metabolism through interactions within the hypothalamus (Zhang et al., 1994; Pelleymounter et al., 1995). However, recent research indicates a role for leptin in regulation of reproductive function.

Due to the long-known relationship between nutritional status and fertility, there has been a search to identify a signal linking adipose tissue stores and the reproductive system. Too little body fat has been shown to be associated with reproductive abnormalities (Frisch, 1990), while obesity is also correlated with reduced fertility. Interestingly, there is a positive correlation between leptin levels and percentage of body fat in humans (Dagago-Jack et al., 1996; Klein et al., 1996; Maffei et al., 1995; Considine et al., 1996). Therefore, it is suggested leptin may serve as the signal from adipose tissue to the reproductive system, indicating whether adequate energy stores are available for normal reproduction (Tataranni et al., 1997).

The role of leptin in regulation of neuroendocrine function, onset of puberty and control of fertility has been the focus of several reviews (Rene-Gonzalez et al., 2000b; Spicer, 2001; Smith et al., 2001; Moschos et al., 2002). However, there is an increasing body of literature suggesting direct effects of leptin on gonadal, gamete and embryo development and function. The objective of this review is to summarize the literature surrounding leptin's mode of action and its impact on development and function of male and female gonads and gametes, as well as its effects on the mammalian preimplantation embryo.

\section{Leptin and the Ovary}

Several lines of evidence have emerged indicating a direct role for leptin in regulation of the mammalian ovary. Firstly, leptin receptor has been identified through the use of RT-PCR in human theca, granulosa (Karlsson et al., 1997; Agarwal et al., 1999; Loffler et al., 2001) and cumulus cells (Cioffi et al., 1997). Similarly, reverse transcription experiments have identified leptin receptor mRNA in porcine ovary, corpus luteum, theca and granulosa cells. (Lin et al., 2000; Ruiz-Cortez et al., 2000), as well as in rat ovarian tissue (Zamorano et al., 1997). Immunohistochemistry has also identified the active form of the leptin receptor in mouse theca and granulosa cells, as well as ovarian stroma and corpra lutea (Ryan et al., 2002).

Secondly, the ovary has been proposed to be a possible site of leptin synthesis. Indeed, leptin and its mRNA have been identified in the human ovary (Cioffi et al., 1997; Loffler et al., 2001). Also, follicular fluid has been found to contain leptin (Karlsson et al., 1997; Barroso et al., 1999; Butzow et al., 1999), suggesting its availability to activate the leptin receptor within the follicle.

Thirdly, in vitro studies have indicated functional roles for leptin in the ovary of several species. High doses of leptin cause a dose dependent decrease in progesterone and androstenedione production by bovine theca cells (Spicer \& Francisco, 1998) and inhibits insulin-like growth factor I (IGF-1)-augmented human thecal cell steroidogenesis (Agarwal et al., 1999). Several studies have also examined effects of leptin on granulosa cell function. Leptin inhibits IFG-1-induced estradiol production by cultured rat (Zachow \& Magoffin 1997) and human granulosa cells (Agarwal et al., 1999) and insulin-induced estradiol production by bovine granulosa cells (Spicer \& Francisco, 1997). Similarly, leptin also inhibits LH-induced estradiol production by human granulosa cells (Karlsson et al., 1997) and impairs the synergistic effect of TFG-â and FSH on estradiol synthesis in rat granulosa cells (Zachow et al., 1999). Furthermore, luteinized human granulosa cells show decreased hCG-induced progesterone production in response to increasing doses of leptin 
(Brannian et al., 1999). These data indicate high levels of leptin may be inhibitory to ovarian function as they seem to attenuate stimulated, but not basal ovarian steroidogenesis. However, it has been reported high doses of leptin can inhibit unstimulated estrogen, but not progesterone production by human granulosa-lutein cells (Ghizzoni et al., 2001). Additionally, physiological levels of leptin are able to inhibit glucocorticoid-induced production of pregnenolone, progesterone, and 20ahydroxy-4-pregnen-3-one in rat granulosa cell lines was increased in the presence of leptin (Barkan et al., 1999). Conversely, it has been found leptin is able to stimulate aromatase activity and estrogen production in luteinized human granulosa cells (Kitawaki et al., 1999). Physiological doses of leptin injected into rats increase adrenodoxin and StAR expression, as well as progesterone secretion, suggesting that the steroidogenic capacity of the rat ovary is elevated, compared to control treatments (Almog et al., 2001). Also, a biphasic effect of leptin was observed in pig granulosa cells, where physiological levels of leptin were stimulatory to steroidogenesis, while only higher levels resulted in inhibition of estrogen production (Ruiz-Cortez et al., 2003).

The majority of studies examining leptin's role in regulation of ovarian steroidogenesis utilize cell culture systems. Unfortunately, these systems don't account for various autocrine/paracrine effects present in the ovary and follicle, which may affect function. Thus, an increasing number of studies have begun to examine the effects of leptin on follicular development and function. It has been reported leptin inhibits FSH-stimulated follicular growth in a dose dependent manner, as well as cAMP and forskolin-induced estrogen production (Kikuchi et al., 2001). In agreement with these findings, increasing doses of leptin during individual follicle culture was also found to inhibit follicle growth (Swain et al., unpublished data.). During follicular culture, it was also found leptin inhibits mouse granulosa cell proliferation (Kikuchi et al., 2001). Conversely, hypertrophy of granulosa cells was observed in rats following leptin injection (Almog et al., 2001) and this injection reduces follicular apoptosis (Almog et al., 2001), suggesting a possible stimulatory effect on growth.

Follicle culture studies have also been utilized to examine ovarian function. Administration of increasing amounts of recombinant mouse leptin to follicular culture increases estrogen, testosterone and progesterone production (Swain et al., unpublished data). Supporting these findings, injection of rats with physiological doses of leptin increases testosterone and progesterone production in the ovary (Cannady et al., 2000). Furthermore, high leptin reduces the number of ovulated oocytes in rats (Duggal et al., 2000). However, it has also been reported physiological doses of leptin injected into rats resulted in higher number of ovulations (Almog et al., 2001). Therefore, it is extremely evident many conflicting reports exist concerning the effects of varying concentrations of leptin on follicular development and function.

Leptin may be responsible for regulatory actions within the ovary, in addition to follicle growth and steroidogenesis. It has been hypothesized leptin may be responsible for regulation of processes involved in luteinization of granulosa cells (Ruiz-Cortes et al., 2003). This is supported by studies showing leptin receptor abundance in porcine granulosa cells increases with luteinization in vitro and in vivo (Ruiz-Cortes et al., 2000).

Further evidence for a direct effect of leptin on the ovary can be seen in alterations in transcriptional activity and signal transduction pathways. Leptin induces c-Jun expression and attenuates the transcriptional activity of the glucocorticoid receptor in granulosa cells, possibly leading to this decreased steroidogenesis (Barkan et al., 1999). Physiological doses of leptin stimulate the JAK-STAT pathway, resulting in increased STAT3 phosphorylation as well as an increase in the concentration of the active form of SREBP1 and StAR promoter activity in porcine granulosa cells (Ruiz-Cortez et al., 2003). However, leptin had no effect on StAR mRNA levels from unstimulated human granulosa-lutein cells (Ghizzoni et al., 2001). 
A possible role for direct effects of leptin in rodent and human testis has been suggested. Leptin receptor has been identified through in situ hybridization in Leydig and Sertoli cells of adult rats (Tena-Sempere et al., 2001). Reverse transcription-PCR studies have also identified leptin receptor mRNA in rat Leydig cells (Caprio et al., 1999; Caprio et al., 2002). Additional studies indicate leptin receptor mRNA is present in testes from pubertal rats, but declines in adulthood (Tena-Sempere et al., 2001 ${ }^{\mathrm{a}, \mathrm{b}}$ ). Leptin receptor has also been identified in human testis (Cioffi et al., 1996). Furthermore, leptin is able to cross the blood-testis barrier (Banks et al., 1999) and is present in human seminal plasma and within the tubuli seminiferi (Camina et al., 2002; Glander et al., 2002), suggesting its availability to interact with its receptor in these tissues.

Functional studies have also revealed a possible direct role of leptin in testes. Rat Leydig cells incubated with increasing levels of leptin led to an inhibition of hCGstimulated testosterone production (Caprio et al., 1999). Leptin also inhibits hCG-stimulated testosterone production in slices of rat testes (Tena-Sempere et al., 1999, 2001a). This inhibition appears to be dependent on the stage of sexual maturation, as inhibition was observed in adult, but not prepubertal rats (Tena-Sempere et al., 1999; Caprio et al., 2002).

Leptin appears to also affect transcription and signal transduction pathways in the male gonad. Leptin decreases mRNA expression of SF-1, StAR and P450 in rat testes (Tena-Sempere et al., 2001 ${ }^{\mathrm{b}}$ ). Additionally, leptin induces STAT3 phosphorylation in mouse seminiferous tubules, as well as phosphorylation of ERK1 and ERK2 in isolated interstitial cells (El-Hefnawy et al., 2000). Finally, addition of leptin to rat testes in vitro results in decreased levels of leptin receptor mRNA (Tena-Sempere et al., 2001')

Indirect evidence for a role of leptin on function and development of testes is apparent from studies utilizing the ob/ob adult male mouse. This mouse is sterile and has abnormal testes, as evidenced by multinucleated spermatids, few spermatozoa and decreased amounts of interstitial Leydig tissue. However, treatment with leptin restores fertility by normalizing testicular weight, spermatogenesis and Leydig cell morphology (Mounzih et al., 1997). Low doses of leptin were also able to restore fertility in young ob/ ob mice (Cleary et al., 2001). Interestingly, high serum leptin concentrations were found in azoospermic compared to normozoospermic men (Steinman et al., 2001), suggesting elevated leptin might be compromising normal sperm production.

\section{Leptin and the Oocyte}

Due to leptin's presence and action in the ovary, research has also focused on a direct role of leptin in regulation of mammalian oocyte function. Supporting the idea of a regulatory role, leptin has been identified through immunocytochemistry in mature preovulatory human oocytes (Cioffi et al., 1997) and via immunohistochemistry in pig oocytes (Ryan et al., 2002). Western blot analysis has also identified the leptin protein in mouse GV-intact and MII oocytes (Antczak \& Van Blerkom, 1997a). Due to the absence of leptin mRNA in these oocytes, it has been suggested the hormone may be maternallyderived and enter the oocyte via a receptor-mediated process, by endocytosis, or by some other unidentified mechanism (Antczak \& Van Blerkom, 1997b; Matsuoka et al., 1999).

Further supporting a key action for leptin in the oocyte, its receptor has been identified in mouse oocytes through immunocytochemical analysis and RT-PCR (Antczak \& Van Blerkom, 1997a; Matsuoka et al., 1999). Mouse oocytes actually contain splice variant forms of the receptor, both OB-Ra and OB-Rb (Kawamura et al., 2002). Pig oocytes also contain leptin receptor (Ryan et al., 2002). Fluorescence-label intensity for leptin receptor in mouse oocytes was more pronounced in MII oocytes, suggesting a possible stage-dependent regulatory role for leptin in oocyte meiosis (Matsuoka et al., 1999). This hypothesis is further supported by the fact that treatment of MII oocytes with physiological levels of leptin results in tyrosine phosphorylation of STAT3 (Matsuoka et al., 1999). Thus, leptin may alter gene transcription during oocyte development. Leptin is asymmetrically localized in the fully-grown GV-intact and MII mouse and human oocytes. 
This localization is coincident with STAT3 distribution and may delineate the future animal pole (Antczak \& Van Blerkom, 1997a). Thus, these proteins may act as regulatory molecules and be involved in subsequent development of the resulting embryo.

Functional studies have also indicated a role for leptin in oocyte development. The addition of leptin during in vitro oocyte maturation advances the onset of germinal vesicle breakdown (GVBD) and reduces cumulus cell coupling in pig oocytes (Galeati et al., 2000). While leptin had no effect on resumption of spontaneous maturation in denuded or cumulus enclosed pig oocytes, it did result in increased rates of GVBD in oocytes cultured within preovulatory follicles (Ryan et al., 2002). Maturation of pig oocytes in the presence of leptin results in altered oocyte metabolism compared to controls (Swain et al., 2001). Subsequent culture of embryos in leptin derived from these leptin-matured oocytes also results in decreased blastocyst development (Swain et al., unpublished data). It is known oocyte metabolism is predictive of subsequent embryo developmental competence and thus may indicate the quality of the maturating oocyte (Krisher \& Bavister, 1999; Spindler et al., 2000). Thus, high doses of leptin may be inhibitory to oocyte developmental competence by causing premature meiotic resumption and/or altering metabolic activity.

Although leptin and its receptor are found within the oocyte, it has been suggested the protein hormone is not required for normal oocyte development. Oocytes from ob/ob mice are able to undergo normal fertilization and embryo development, resulting in pregnancy and live birth, following transplant to a normal surrogate (Runner \& Gates, 1954). Similarly, transplant of ovaries from obese mothers to normal surrogates result in offspring (Hummel, 1957). Finally, treatment of ob/ob females with exogenous gonadotropins also allows for successful ovulation, fertilization and embryo development (Smithberg \& Runner, 1957), suggesting the sterility defect in these obese mice is not at the level of the oocyte. Supporting this notion, in vitro maturation of cumulus enclosed mouse oocytes in the presence of leptin had no effect on GVBD or MII development (Swain et al., unpublished data). Similarly, oocytes isolated from mouse follicles cultured for $9 \mathrm{~d}$ in the presence of varying doses of leptin had no differences in GVBD or MII following in vitro maturation (Swain et al., unpublished data). A similar study in rats showed no effect on meiotic resumption in oocytes isolated from gonadotropin-stimulated follicles (Duggal et al., 2002). Thus, it remains to be determined whether leptin is required for normal oocyte development and function.

\section{Leptin and Sperm}

Functional leptin receptor has also been identified in male mouse germ cells (El-Hefnawy et al., 2000). Immunohistochemistry revealed age and stage dependent distribution of leptin receptor throughout the testis, showing expression in spermatogonia of young mice and localization to spermatocytes in adults (El-Hefnawy et al., 2000). It is suggested leptin may be responsible for regulation of growth and differentiation of these developing germ cells.

Leptin may also be involved in regulating sperm function. Leptin levels show a negative correlation with percentage of motile spermatozoa (Glander et al., 2002). However, is has been reported there is no correlation between leptin levels and sperm concentration, motility, vitality or morphology (Camina et al., 2002). Thus, additional research is required to elucidate leptin's role in regulation of sperm development and function.

\section{Leptin and the Preimplantation Embryo}

There is a growing amount of literature indicating a direct role for leptin in regulation of preimplantation embryo development. It has been shown leptin is differentially distributed and coincident with STAT3 between daughter blastomeres in cleavage stage embryos, the inner and outer cells of the morula, and the inner cell mass and trophectoderm of the blastocyst. (Antczak \& Van Blerkom, 1999). The authors suggest that this distribution may be of developmental significance, possibly 
involved in regulation of gene transcription, aiding in the understanding of fragmentation of the embryo, or establishment of the inner cell mass and trophectoderm in the blastocyst. Also, leptin is present in the oocyte and therefore may play a role in early stages of preimplantation embryo development. Leptin mRNA is present in the mouse blastocysts and hatched blastocysts (Kawamura et al., 2002), indicating that, at these stages, mouse embryos are actively making the protein hormone. Indeed, it has been reported human blastocysts secrete leptin, and that levels are higher than arrested embryos (Gonzalez et al., 2000).

Leptin receptor has also been identified in the mammalian preimplantation embryo. Leptin OB-R receptor has been identified in mouse embryos using immunofluoresence, showing localization to the nuclear region with diffuse cytoplasmic staining (Antczak \& Van Blerkom, 1999). Both OB-Ra and OB-Rb mRNAs were detected in oocytes, decreased at the 2-cell stage, and increased in morula stage embryos (Kawamura et al., 2002), indicating a switch of leptin responsiveness from maternal to embryonic control.

Several in vitro studies have shown a direct functional effect of leptin on embryo development. Culture of 2-cell or 8 -cell embryos in leptin at $10 \mathrm{ng} / \mathrm{ml}$ is able to increase development to the blastocyst stage, while $100 \mathrm{ng} / \mathrm{ml}$ of leptin at the 2-cell stage is inhibitory (Herrid \& McFarlane, 2001), indicating a possible dose and stage dependent response. Also, maturation of porcine oocytes and culture of subsequent embryos in the presence of increasing doses of leptin reduces blastocyst development (Swain et al., 2001). However, addition of leptin to 1-cell mouse embryos at varying doses had no effect on subsequent cleavage or degeneration at 24 hours, or to blastocyst or hatched blastocyst by 96 hours (Swain et al., unpublished data). Similarly, addition of leptin during in vitro culture of porcine embryos had no effect on blastocyst development (Swain et al., 2001). Contradicting these findings are reports that increasing doses of leptin during mouse embryo culture increase development to blastocyst, expanded blastocyst and hatched blastocyst stages (Kawamura et al., 2002). These data were supported by the observed inhibitory response to rate of blastocyst formation when mouse embryos were cultured in the presence of leptin and anti-OB-R antibody (Kawamura et al., 2002). Furthermore, leptin increases total blastocyst cell number by increasing proliferation of trophectoderm and inner cell mass (Kawamura et al., 2002).

Indirect evidence for a regulatory role on leptin on the developing preimplantation embryo also exists. Leptin levels have been negatively correlated with human follicular oxygen content and may be a marker of follicular hypoxia (Barroso et al., 1999), which may result in compromised embryo development. Also, patients who successfully became pregnant from IVF had lower follicular fluid (Mantzoros et al., 2000) and serum levels of leptin than those who did not (Brannian et al., 2001). Lower leptin levels in these patients resulted in a greater proportion of high quality embryos, yet had no effect on number of mature oocytes retrieved or fertilized, suggesting leptin may be affecting post-fertilization events, such as embryo development or implantation (Brannian et al., 2001). Additionally, leptin mRNA was detected in mouse oviduct and uterus, while immunohistochemical staining indicated leptin was more abundant in these tissues of pregnant mice, compared to virgins (Kawamura et al., 2002). Uterine fluid contains detectable levels of leptin, while oviductal fluid does not (Kawamura et al., 2002), suggesting a possibly direct role of leptin in normal blastocyst function. Human endometrium contains mRNA for both leptin and the long form of the leptin receptor (Rene-Gonzalez et al., 2000a). Therefore, leptin may serve as a signal for implantation between the blastocyst and human endometrium. These data suggest leptin may exert some sort of stage regulatory action on the developing preimplantation embryo as it migrates through the reproductive tract. 


\section{Concluding Remarks}

Based on a review of the literature, it is apparent there is an abundance of contradictory information regarding the direct effects of leptin on the mammalian gonads, gametes and preimplantation embryo. However, considering the present data, it appears as if leptin is directly regulating gonadal, gamete and preimplantation development and function. These direct effects may be contributing to altered fertility in overweight patients with elevated levels of leptin.

\section{Acknowledgments} manuscript.

\section{References}

Agarwal SK, Vogel K, Weitsman SR, Magoffin DA. Leptin antagonizes the insulin like growth factor I augmentation of steroidogenesis in granulosa and theca cells of the human ovary. J Clin Endo Metab 1999;84(3):1072-6.

Almog B, Gold R, Tajima K, Dantes A, Salim K, Rubinstein M, Barkan D, Homburg R, Lessing JB, Nevo N, Gertler A, Amsterdam A. Leptin attenuates follicular apoptosis and accelerates the onset of puberty in immature rats. Mol Cell Endo 2001;183:179_ 91.

Antczak M, Van Blerkom J. Oocyte influences on early development: the regulatory proteins leptin and STAT3 are polarized in mouse and human oocytes and differentially distributed within the cells of the preimplantation stage embryo. Mol Hum Reprod 1997a;3(12):1067-86.

Antczak M, Van Blerkom J. Temporal and spatial aspects of fragmentation in early human embryos: possible effects on developmental competence and association with the differential elimination of regulatory proteins from polarized domains. Hum Reprod 1999;14(2):429-47.

Antczak M, Van Blerkom J, Clark A. A novel mechanism of vascular endothelial growth factor, leptin and transforming growth factor- B2 sequestration in subpopulation of human ovarian follicle cells. Hum Reprod 1997b;12(10):2226-34.

Banks WA, McLay RN, Kastin AJ, Sarmiento U, Scully S. Passage of leptin across the blood-testis barrier. Am J Physiol 1999;276:1099-104.

Barkan D, Jia H, Dantes A, Vardimon L, Amsterdam A, Rubinstein M. Leptin modulates the glucocorticoid induced ovarian steroidogenesis. Endocrinology 1999;140(4):17318.

Barroso G, Barrionuevo M, Rao P, Graham L, Danforth D, Huey S, Abuhamad A, Oehninger S. Vascular endothelial growth factor, nitric oxide, and leptin follicular fluid levels correlate negatively with embryo quality in IVF patients. Fertil Steril 1999;72:1024-6.

Brannian JD, Schimdt SM, Kreger DO, Hansen KA. Baseline non-fasting serum leptin concentration to body mass index ration is predictive of IVF outcomes. Hum Reprod 2001;6(9):1819-26.

Brannian JD, Zhao Y, McElroy M. Leptin inhibits gonadotropin stimulated granulosa cell progesterone production by antagonizing insulin action. Hum Reprod 1999;14(6):14458.

Butzow TL, Moilanen JM, Lehtovirta M, Tuomi T, Hovatta O, Siegber R, Nilsson CG, Apter D. Serum and follicular fluid leptin during in vitro fertilization: relationship among leptin increase, body fat mass, and reduced ovarian response. J Clin Endocrinol Metab 1999;84:3135-9.

Camina J:P, Lage M, Menendez C, Grana M, Garcia-Devesa J, Dieguez C, Casanueva FF. Evidence of free leptin in human seminal plasma. Endocrinol 2002;17(3):169-74.

Cannady WE, Brann DW, Mahesh VB. The potential role of periovarian fat and leptin in initiation of puberty in the immature rat. Int J Obes Relat Metab Disord 2000;Suppl 
2:146-7.

Caprio M, Fabbrini E, Ricci G, Basciani S, Gnessi L, Arizzi M, Carta AR, De Martino MU, Isidori AM, Frajese GV, Fabbri A. Ontogenesis of leptin receptor in rat Leydig cells. Biol Reprod 2003 68(4):1199-207

Caprio M, Isidori AM, Carta AR, Moretti C, Duau ML, Fabbri A. Expression of functional leptin receptors in rodent Leydig cells. Endocrinol 1999;140(11):4939-47.

Cioffi JA, Shafer AW, Zupancic JW, Smith-Gbur J, Mikhail A, Platika D, Snodgrass HR. Novel B219/OB receptor isoforms: possible role of leptin in hematopoiesis and reproduction. Nat Med 1996;2(5):585-9.

Cioffi JA, Van Blerkom J, Antczak M, Shafer A, Wittmer S, Snodgrass HR. The expression of leptin and its receptors in pro-ovulatory human follicles. Mol Hum Reprod 1997;3(6):467-72.

Cleary MP, Bergstrom HM, Dodge TL, Getzin SC, Jacobson MK, Phillips FC. Restoration of fertility in young obese (Lep(ob) Lep(ob)) male mice with low dose recombinant mouse leptin treatment. Int J Obes Relat Metab Disord 2001;25(1):95-7.

Considine RV, Sinha MK, Heiman ML, Kriauciunas A, Stephens TW, Nyce MR, Ohannesian JP, Marco CC, McKee LJ, Bauer TL, Caro JF. Serum immunoreactive leptin concentration in normal weight and obese humans. New Eng J Med 1996;334:292-5.

Dagago-Jack S, Fanelli C, Paramore D, Brothers J, Landt M. Plasma leptin and insulin relationship in obese and nonobese humans. Diabetes 1996;45:695-8.

Duggal PS, Van der Hoek KH, Milne CR, Yan NK, Armstrong DT, Magoffin DA, Normann RJ. The in vivo and in vitro effects of exogenous leptin on ovulation in the rat. Endocrinology 2000;141(6):1971-6.

Duggal PS, Weitsmann SR, Magoffin DA, Normann RJ. Expression of the long (OB_RB) and short (OB_RA) forms of the leptin receptor throughout the oestrous cycle in the mature rat ovary. Reprod 2002; 23:899-905.

El-Hefnawy T, Ioffe S, Dim M. Expression of the leptin receptor during germ cell development in the mouse testis. Endocrinology 2000; 41(7):2624-30.

Frisch RE. The right weight: body fat, menarche and ovulation. Ballieres Clin Gynaecol 1990;4:419-39.

Galeati G, Govoni N, Spinaci A, Parmeggiani A, Fantinati P, Mattioli M. Effect of fasting and refeeding on plasma and follicular fluid leptin levels in prepubertal gilts. Reproduction. 2003;126(5):647-52.

Ghizzoni L, Barreca A, Mastorakos G, Furlini M, Vottero A, Ferrari B, Chrousos GP, Bernasconi S. Leptin inhibits steroid biosynthesis by human granulosa-lutein cells. Horm Meab Res 2001;33(6):323-8.

Glander HJ, Lammert A, Paasch U, Glasow A, Kratzsch J. Leptin exists in tubuli seminferi and in seminal plasma. Andrologia 2002;34:227-33.

Gonzalez RR, Caballero-Campo P, Jasper M, Mercader A, Devoto L, Pellicer A, Simon C. Leptin and leptin receptor are expressed in the human endometrium and endometrial leptin secretion is regulated by the human blastocyst. J Clin Endocrinol Metab. 2000;85(12):4883-8.

Herrid M, McFarlane JR. The effect of leptin on mouse embryo development in vitro: dose and stage dependent regulation. Proc 32 And Annual Conf Soc Reprod Biol, Reprod Fertil Dev. 2001; Abstr 47.

Hummel KP. Transplantation of ovaries of the obese mouse. Anat Rec 1957;128:596.

Karlsson C, Lindell K, Svensson E, Bergh C, Lind P, Billig H, Carlsson LMS, Carlsson B. Expression of functional leptin receptors in the human ovary. J Clin Endocin Metab 1997;32(12):4144-8.

Kawamura K, Sato N, Fukuda J, Kodama H, Kumagai J, Tanikawa H, Nakamura A, Tanaka T. Leptin promotes the development of mouse preimplantation embryos in vitro. Endocrinology 2002;143(5):1922-31.

Kikuchi N, Andohg K, Abe Y, Yamada K, Mizunuma H, Ibuki Y. Inhibitory action of leptin on early follicular growth differs in immature and adult female mice. Biol Reprod 
2001;65:66-71.

Kitawaki J, Kusiuki I, Koshiba H, Tsukamoto K, Honjo H. Leptin directly stimulates aromatase activity in human luteinized granulosa cells. Mol Hum Reprod 1999;5(8):70813.

Klein S, Coppack SW, Mohamed AV, Landt M. Adipose tissue leptin production and plasma leptin kinetics in humans. Diabetes 1996;45(7):984-7.

Krisher RL. Bavister BD. Enhanced glycolysis after maturation of bovine oocytes in vitro is associated with increased developmental competence. Mol Reprod Dev 1999;53(1):19-26.

Lin J, Barb CR, Matteri RL, Kraelin RR, Chen X, Meinersmann RJ, Rampacek GB. Long form leptin receptor mRNA expression in the brain, pituitary and other tissues in pig. Dom Anim Endo 2000;19(1):53-61.

Loffler S, Augst G, Kohler U, Spanel-Borowski K. Evidence of leptin expression in normal and polycystic human ovaries. Mol Hum Reprod 2001;7(12):1143-9.

Maffei M, Halaas J, Ravussin E, Pratley RE, Lee GH, Zhang Y, Fei H, Kim S, Lallone R, Ranganathan S. Leptin levels in human and rodent: measurement of plasma leptin and ob RNA in obese and weight reduced subjects. Nat Med 1995;1:1155-61.

Mantzoros CS, Cramer DW, Liberman RF, Barbieri RL. Predictive value of serum and follicular fluid leptin concentrations during assisted reproductive cycles in normal women and in women with the polycystic ovarian syndrome. Hum Reprod. 2000;15(3):539-44

Matsuoka T, Tahara M, Yokoi T, Masumotoa N, Takeda T, Yamaguchi M, Tasaka K, Kurachi H, Murata Y. Tyrosine phosphorylation of STAT3 by leptin though leptin receptor in mouse metaphase 2 stage oocyte. Biochem Biophys Res Comm 1999;256:480-4.

Moschos S, Chan JL, Mantzoros CS. Leptin and reproduction: a review. Fertil Steril 2002;77(3):433-44.

Mounzih K, Ronghua L, Chehab FF. Leptin treatment rescues the sterility of genetically obese ob/ob males. Endocrinology 1997;138(3):1190-3.

Pellymounter MA, Cullen MJ, Baker MB, Hecht R, Winters D, Boone T, Collins F. Effects of the obese gene product on body weight regulation in ob/ob mice. Science 1995;269:540-3.

Rene-Gonzalez R, Caballero-Campo P, Jasper M, Mercader A, Devoto L, Pellicer A, Simon C. Leptin and leptin receptor are expressed in the human endometrium and endometrial leptin secretion is regulated by the human blastocyst. J Clin Endo Metab 2000a;85(12):4883-8.

Rene-Gonzalez R, Simon C, Caballero Campo-P, Norman R, Chardonnens D, Devoto L, Bischof P. Leptin and reproduction. Hum Reprod Update 2000b;6(3):290-300.

Ruiz-Cortes ZT, Martel-Kennes Y, Gevry NY, Downey BR, Palin MF, Murphy BD. Biphasic effects of leptin in porcine granulosa cells. Biol Reprod 2003;68:780-96.

Ruiz-Cortes ZT, Men T, Palin MF, Downey BR, Lacroiz DA, Murphy BD. Porcine leptin receptor: molecular structure and expression in the ovary. Mol Reprod Dev 2000;56:46574.

Runner MN, Gates A. Sterile obese mothers. J Hered 1954;45:51-5.

Ryan NK, Woodhouse CM, Van der Hoek KH, Gilchrist RB, Armstrong DT, Norman RJ. Expression of leptin and its receptor in the murine ovary: possible role in the regulation of oocyte maturation. Biol Reprod 2002;66:1548-54.

Smith GD, Jackson LM, Foster DL. Leptin regulation of reproductive function and fertility. Therio 2001;57:73-86.

Smithberg M, Runner MN. Pregnancy induced in genetically sterile mice. J Hered 1957;48:97-100.

Spicer LJ. Leptin: a possible metabolic signal affecting reproduction. Domestic Animal Endocrinology 2001;21:251-70.

Spicer LJ, Francisco CC. The adipose obese gene product, leptin. Evidence of a direct inhibitory role in ovarian function. Endocrinology 1997;138(8):3374-9. 
Spicer LJ, Francisco CC. Adipose obese gene product, leptin, inhibits bovine ovarian thecal cell steroidogenesis. Biol Reprod 1998;58:207-12.

Spindler, R.E., Pukazhentihi, B.S., Wildt, D.E. Oocyte metabolism predicts the development of cat embryos to blastocyst in vitro. Mol Reprod Dev 2000;56:163-71.

Steinman N, Gamzu R, Yogev L, Botchan A, Schreiber L, Yavetz H. Serum leptin concentrations are higher in azoospermic than normozoospermic men. Fertil Steril 2001;75(4):821-2.

Swain JE, Bormann CL, Krisher RL. Effects of leptin on porcine oocyte maturation and embryo development in vitro. Biol Reprod. 2001;Suppl. 64(1) Abstr. 269.

Tataranni PA, Monroe MB, Dueck CA. Adiposity, plasma leptin concentration and reproductive function in active and sedentary females. Int J Obes Relat Metab Disord 1997;21:818-21.

Tena-Sempere M, Manna PR, Zhang FP, Pnilaa L, Gonzalez LC, Dieguez C, Huhtaniemi I, Aguilar E. Molecular mechanisms of leptin action in adult rat testis: potential targets for leptin induced inhibition of steroidogenesis pattern of leptin receptor messenger ribonucleic acid expression. J Endo 2001a;170:413-23.

Tena-Sempere M, Pinilla L, Gonzalez LC, Dieguez C, Casanueva FF, Aguilar E. Leptin inhibits testosterone secretion from adult rat testis in vitro. J. Endo 1999;161:211-8.

Tena-Sempere M, Pinilla L, Zhang FP, Gonzalez LC, Huhtaniemi I, Casanueva FF, Dieguez C, Aguilar E. Developmental and hormonal regulation of leptin receptor (Ob-R) messenger ribonucleic acid expression in rat testis. Biol Reprod 2001b;64:634-43.

Zachow RJ, Magoffin DA. Direct intraovarian effects of leptin: impairment of the synergistic action of insulin like growth factor I on follicle stimulating hormone dependent estradiol $17 \mathrm{~N}$ production by rat ovarian granulosa cells. Endocrinology 1997;128(2):847-50.

Zachow RJ, Witsman SR, Magoffin DA. Leptin impairs the synergistic stimulation by transforming growth facto B of follicle stimulating hormone dependent aromatase activity and messenger ribonucleic acid expression in rat ovarian granulosa cells. Biol Reprod 1999;61:1104-9.

Zamorano PL, Mahesh VB, De Sevilla LM, Chorich LP, Bhat GK, Brann DW. Expression and localization of the leptin receptor in endocrine and neuroendocrine tissues of the rat. Neuroendocrinology 1997;65:223-8.

Zhang Y, Proenca R, Maffei M, Barone M, Leopold, L, Friedman JM. Positional cloning of the mouse obese gene and its human homologue. Nature 1994;372:425-32. 